\title{
LA TIERRA Y SUS RECLAMOS
}

\section{THE EARTH AND ITS CLAIMS}

\section{José Manuel Silvero Arévalos ${ }^{1}$}

Nos toca atravesar una época en que la velocidad se ha vuelto una cuestión central en la gestión de la vida y quizás, especialmente, en la administración de la experiencia humana. Nos autopercibimos en extremo expeditivos, eficientes, exactos y hasta infalibles. La poderosa idea (ficción) de que todo, absolutamente todo, se encuentra a un clic de distancia, probablemente ha impregnado en nuestro carácter y en nuestras convicciones, la imagen del devenir atrapado en una pantalla. La extensión del cerebro en términos insospechados. El tiempo pasado, el que está transcurriendo y el venidero, juntos incluso, todo eso, pretendemos portarlo en la palma de la mano. Así, los algoritmos se encargan de ajustar, seleccionar y potenciar la memoria y la conciencia de un presente preñado de un futuro a la medida de ciertos intereses que, paradójicamente, "nos invitan a liberarnos de la obligación de un futuro".

${ }^{1}$ DGICT, Universidad Nacional de Asunción - Paraguay. Contacto: jmsilverouna@gmail.com 
Entonces, ¿cómo podríamos seguir creyendo en ese viejo ideal humanista de emancipación que, al superar siglos de sumisión, silencio y superstición, propició que creyéramos en nosotros mismos y nos animó a caminar sin tutelajes por los senderos de la educación, la racionalidad, la fraternidad y, muy especialmente, por la senda de la responsabilidad de nuestros actos y nuestras decisiones? Al parecer, nunca antes hemos creído tanto en nosotros mismos como ahora. Incluso, nunca antes hemos creído tan angustiosamente que nuestras opiniones (vertidas en una pantalla) merecen absoluto respeto y, además, se transforman en insumos preciosos y gravitantes a la hora de que las autoridades 0 las grandes corporaciones deban tomar decisiones acerca del presente inmediato y del futuro. $Y$ una de las cosas que miles y millones de seres humanos están "pensando" en este momento es en la grave situación por la que atraviesa la tierra. Ya sea por los altos índices de contaminación, como por los incendios forestales en varios lugares del mundo y muy especialmente en el Amazonas. $Y$ esa preocupación se traduce en reclamos, enojos, ideas, estrategias, imágenes, emoticones y muchos datos más.

La idea de progreso, esa que nos empuja hacia adelante y nos promete mejores condiciones de vida y así sucesivamente, está presente en todos los órdenes de la vida. $Y$ una nota, sello distintivo, característica, es justamente ese fluir (vertiginosamente) hacia adelante. Sin embargo, conscientes estamos de que así como hemos logrado tantas conquistas maravillosas, así también una gran amenaza pende sobre nuestras cabezas a causa de ciertas decisiones y acciones que hemos desplegado de manera sostenida desde hace un buen tiempo.

Por ello, vale pensar, tal como lo hiciera en su momento Aldo Leopold, que la tierra es un sistema ecológico dinámico y, al mismo tiempo, una comunidad moral de la que todos los seres formamos parte. Leopold (1949) afirma que maltratamos la Tierra porque la consideramos un producto que nos pertenece. Entonces propone que la asumamos como una comunidad a la que pertenecemos, 
quizá así empecemos a tratarla con amor y respeto. Ante la desmesura y el maltrato que la Tierra recibe, Leopold es contundente: la tierra no podrá sobrevivir. De ahí la necesidad de que nos sintamos parte de ella. De lo contrario, "no hay ninguna otra manera de que la Tierra sobreviva al impacto del ser humano mecanizado, ni de que nosotros recojamos la cosecha, sembrada de ciencia, capaz de contribuir a la cultura".

La propuesta de sortear los límites de la ética antropocéntrica e integrar en la comunidad ética a aquellos que se pueden ver dañados por el hombre en la simbiosis evolutiva, esto es, a los suelos, las aguas, las plantas y los animales, es la gran apuesta de Leopold.

La Tierra no es solamente superficie, sino una comunidad donde convivimos los animales, las plantas, los cauces hídricos, en fin, ese gran colectivo. Por ello, la ética debe ampliarse a la "Tierra". Es una posibilidad evolutiva y una necesidad ecológica. Ni una ni otra pueden dejarse a merced del actual trato que recibe: mera mercancía de la conquista humana. (Lecaros, 2008)

Ese amor a la "comunidad", a la "vida", ese afecto, justamente ha sido la razón que tan triste $y$ trágicamente acabó con la vida de Leopold al intentar combatir un incendio en una granja vecina.

\section{Yvypóra}

En la sabiduría guaraní hay conceptos filosóficos muy válidos para estos tiempos, que incluso, anteceden a las reflexiones del gran Aldo Leopold. Voy a citar dos como ejemplos. Tekoha (teko: vida; ha: existencia). Este concepto desborda la simple idea de extensión, superficie o terreno. Arropa y contiene la representación de un espacio que soporta la existencia del ser. Ser con historia, hacedor de su destino respetuoso de la tierra de la que forma parte y al mismo tiempo "es". 
La segunda idea es Yvypóra (yvy: tierra, póra: imagen, espectro). El término imprime un carácter subsidiario, incluso dependiente y necesario de ese "ser", reflejo, imagen de una entidad, "comunidad" (diría Leopold), que la excede, pues de ella ha emergido y a ella el destino convoca. El espectro que surge "de" y se apagará "en".

Entonces, desde la sabiduría guaraní no hay reclamos. Pues, no se puede reclamar lo que se "es". En todo caso, valdría pensar si hemos dejado de creer en nuestra condición de Yvypóra y nos aferramos de manera entusiasta a la idea de que el poshumanismo y la fuerza de la técnica y los algoritmos nos regalarán la solución y el acomodo que el progreso tan generosamente nos depara.

\section{Referencias}

- Silvero Arévalos, J.M. 2019. La tierra y sus reclamos (Edición Original). Diario Última Hora: https://www.ultimahora.com/latierra-y-sus-reclamos-n2841260.html

. 2021. La tierra y sus reclamos (Primera Reproducción). Yrape, Escritos Pandémicos https://yrape.blogspot.com/2021/02/yrape.html?m=0 